\title{
DETERMINATION OF THE MAXIMUM INHIBITORY DILUTION OF CETYLPYRIDINIUM CHLORIDE-BASED MOUTHWASHES AGAINST STAPHYLOCOCCUS AUREUS: AN IN VITRO STUDY
}

\author{
Evandro WATANABE ${ }^{1}$, Juliane Maria Guerreiro TANOMARU ${ }^{2}$, Andresa Piacezzi NASCIMENTO ${ }^{1}$, \\ Fumio MATOBA-JÚNIOR ${ }^{3}$, Mario TANOMARU-FILHO ${ }^{4}$, Izabel Yoko ITO
}

\begin{abstract}
1- MSc, PhD Student in Microbiology, Pharmaceutical Sciences School of Ribeirão Preto, University of São Paulo, Ribeirão Preto, SP, Brazil. 2- DDS, MSc, PhD, Assistant Professor, Department of Restorative Dentistry, Dental School of Araraquara, São Paulo State University, Araraquara, SP, Brazil.

3- DDS, MSc Student in Pediatric Dentistry, Dental School of Ribeirão Preto, University of São Paulo, Ribeirão Preto, SP, Brazil.

4- DDS, MSc, PhD, Associate Professor, Department of Restorative Dentistry, Dental School of Araraquara, São Paulo State University, Araraquara, SP, Brazil.

5- MSc, PhD, Full Professor of Microbiology, Pharmaceutical Sciences School of Ribeirão Preto, University of São Paulo, Ribeirão Preto, SP, Brazil.
\end{abstract}

Corresponding address: Profa. Dra. Juliane Maria Guerreiro Tanomaru, Rua Humaitá, 1901, Ap. 182. Araraquara, SP, Centro - 14801-385, Brazil. Phone: +55-16-3301-6390, Fax: +55-16-3301-6392 - e-mail: jutanomaru@uol.com.br

Received: June 29, 2007 - Modification: March 4, 2008 - Accepted: March 27, 2008

\begin{abstract}
$T_{\text {he }}$

he aim of this in vitro study was to determine the maximum inhibitory dilution (MID) of four cetylpyridinium chloride (CPC)based mouthwashes: CPC+Propolis, $\mathrm{CPC}+$ Malva, $\mathrm{CPC}+$ Eucaliptol+Juá+Romã+Propolis $\left(\right.$ Natural Honey $\left.{ }^{\circledR}\right)$ and $\mathrm{CPC}\left(\mathrm{Cepacol}^{\circledR}\right)$, against 28 Staphylococcus aureus field strains, using the agar dilution method. Decimal dilutions ranging from 1/10 to 1/ 655,360 were prepared and added to Mueller Hinton Agar. Strains were inoculated using Steers multipoint inoculator. The inocula were seeded onto the surface of the culture medium in Petri dishes containing different dilutions of the mouthwashes. The dishes were incubated at $37^{\circ} \mathrm{C}$ for $24 \mathrm{~h}$. For readings, the MID was considered as the maximum dilution of mouthwash still capable of inhibiting microbial growth. The obtained data showed that $\mathrm{CPC}+$ Propolis had antimicrobial activity against 27 strains at 1/320 dilution and against all 28 strains at 1/160 dilution, CPC+Malva inhibited the growth of all 28 strains at 1/320 dilution, CPC+Eucaliptol+Juá+Romã+Propolis inhibited the growth of 2 strains at 1/640 dilution and all 28 strains at $1 / 320$ dilution, and $\mathrm{Cepacol}^{\circledR}$ showed antimicrobial activity against 3 strains at $1 / 320$ dilution and against all 28 strains at $1 / 160$ dilution. Data were submitted to Kruskal-Wallis test, showing that the MID of Cepacol ${ }^{\circledR}$ was lower than that determined for the other products $(\mathrm{p}<0.05)$. In conclusion, $\mathrm{CPC}$-mouthwashes showed antimicrobial activity against $S$. aureus and the addition of other substances to CPC improved its antimicrobial effect.
\end{abstract}

Key words: Bacteria. Mouthwashes. Cetylpyridinium chloride.

\section{INTRODUCTION}

Currently, a wide range of options in oral antiseptics and toothpastes is available in the market. These products contain synthetic and/or natural compounds with antimicrobial activity ${ }^{12}$.

Among these synthetic compounds is cetylpyridinium chloride (CPC), a quaternary ammonium compound included in the group of the cationic surface-active agents ${ }^{18}$. It acts primarily by penetrating the cell membrane, causing leakage of cell components, disruption of the bacterial metabolism, inhibition of cell growth, and finally, cell death ${ }^{3}$.

Natural extracts, such as propolis, Malva sylvestris,
Punica granatum, Zizyphus joazeiro, Eucalyptus globulus, and Salvadora persica are included in the formulation of commercially available oral hygiene products. The addition of these substances aims to improve the antibacterial action, since these natural extracts have demonstrated effect against a wide range of microorganisms ${ }^{23}$. The antibacterial action of CPC-based mouthwashes is variable and depends on the product's formulation ${ }^{10}$.

Staphylococcus aureus is a major human pathogen, responsible for a number of hospital-acquired infections ${ }^{17}$. This microorganism is able to colonize several locations in the human body, but mouth, hands, and nasopharynges are the main reservoirs for propagation of this germ in the 
hospital environment ${ }^{15}$. Therefore, control of S. aureus is extremely relevant for the determination of the antiseptic properties of hygiene products. The increased occurrence of methicillin-resistant $S$. aureus strains (MRSA), as well as of other strains resistant to different broad-spectrum antimicrobial agents, represents a therapeutic challenging situation ${ }^{5}$. Among the microorganisms present in the oral cavity, the reduction in the number of $S$. aureus prior to surgical procedures has been associated with a lower incidence of infective endocarditis and postoperative infections ${ }^{1}$.

The purpose of this in vitro study was to determine the maximum inhibitory dilution (MID) of CPC-based mouthwashes and other products containing natural extracts in addition to CPC against $28 \mathrm{~S}$. aureus field strains.

\section{MATERIALAND METHODS}

The following CPC-based products were evaluated: Cepacol $^{\circledR}$ (Aventis Pharma Ltda., São Paulo, SP, Brazil), Natural Honey CPC + Propolis (Skill Brothers Indústria e Comércio Ltda, São Paulo, SP, Brazil), Natural Honey CPC
+ Malva (Skill Brothers Indústria e Comércio Ltda.), and Natural Honey CPC + Eucaliptol $+J u a ́+$ Romã + Propolis (Skill Brothers Indústria e Comércio Ltda.) (Table 1).

MID determination was performed in duplicate by double serial dilution (from $1 / 10$ through $1 / 655,360$ ) in test tubes $(20 \times 200 \mathrm{~mm})$ with $2.0 \mathrm{~mL}$ of sterile distilled water. After dilutions, $18.0 \mathrm{~mL}$ of Mueller Hinton Agar culture medium (Difco ${ }^{\circledR}$, USA) were added to each tube, and the resulting solutions were poured onto Petri dishes $(20 \times 100 \mathrm{~mm})$.

The microbial inoculum $\left(\sim 10^{8} \mathrm{cfu} / \mathrm{mL}\right)$ with turbidity equivalent to a $\# 0.5 \mathrm{McF}$ arland standard was prepared in test tubes $(15 \times 125 \mathrm{~mm})$ with saline, using $28 \mathrm{~S}$. aureus field strains obtained from nasal and oral cavities. The strains were conserved on a collection cultured on $\mathrm{Ni}$ agar medium. The identification of $S$. aureus was based on the production of catalase and coagulase. Regardless of the results of the coagulase test, all catalase positive Gram-positive cocci were submitted to the API-Staph system (bioMérieux, France) for biochemical identification.

Microorganisms were seeded using a Steers multipoint inoculator ${ }^{27}$. The Steers inoculator consists of two metallic plates. One plate has 25 wells onto which $200 \mu \mathrm{L}$ of each standardized microbial inoculum were transferred. The other

TABLE 1- Chemical composition of the antiseptic solutions evaluated

\begin{tabular}{|c|c|c|}
\hline Antiseptic & Composition & \\
\hline Cepacol $^{\circledR}$ & $\begin{array}{l}\text { - Cetylpyridinium chloride } \\
\text { - Disodium EDTA } \\
\text { - Sodium saccharin } \\
\text { - Polysorbate } 80 \\
\text { - Glycerin } \\
\text { - Water } \\
\text {-Sodium phosphate monobasic } \\
\text { anhydrous }\end{array}$ & $\begin{array}{l}\text { - Eucalyptol } \\
\text { - Menthol } \\
\text { - Methyl salicilate } \\
\text { - Mint oil } \\
\text { - Chinese cinnamon flavor } \\
\text { - Yellow tartrazine } \\
\text { - Ethyl alcohol 96GL }\end{array}$ \\
\hline $\begin{array}{l}\text { Natural Honey } \\
\text { CPC+Propolis }\end{array}$ & $\begin{array}{l}\text {-Natural propolis extract } \\
\text { - Sodium fluoride } 0.05 \% \text { (226ppmF) } \\
\text { - Cetylpyridinium chloride (CPC) } \\
\text { - Sorbitol } \\
\text { - Sodium phosphate monobasic } \\
\text { - Sodium phosphate dibasic }\end{array}$ & $\begin{array}{l}\text { - Ethanol } \\
\text { - Sorbitan monolaurate } \\
\text { - Sodium saccharin } \\
\text { - Cl42.053 green } \\
\text { - Mint flavor } \\
\text { - Demineralized water }\end{array}$ \\
\hline $\begin{array}{l}\text { Natural Honey } \\
\text { CPC+Malva }\end{array}$ & $\begin{array}{l}\text { - Natural Malva sylvestris extract } \\
\text { - Sodium fluoride } 0.05 \% \text { (226ppmF) } \\
\text { - Cetylpyridinium chloride(CPC) } \\
\text { - Sorbitol } \\
\text {-Sodium phosphate monobasic } \\
\text {-Sodium phosphate dibasic }\end{array}$ & $\begin{array}{l}\text { - Ethanol } \\
\text { - Sorbitan monolaurate } \\
\text { - Sodium saccharin } \\
\text { - Cl42.090 blue } \\
\text { - Mint flavor } \\
\text { - Demineralized water }\end{array}$ \\
\hline $\begin{array}{l}\text { Natural Honey } \\
\text { CPC + Eucaliptol + Juá + } \\
\text { Romã + Propolis }\end{array}$ & $\begin{array}{l}\text {-Natural extracts of pomegranate, } \\
\text { propolis, and Zizyphus joazeiro } \\
\text {-Eucalyptol } \\
\text {-Methyl salicilate } \\
\text {-Sodium fluoride } 0.05 \% \text { (226ppmF) } \\
\text {-Cetylpyridinium chloride(CPC) } \\
\text {-Sorbitol }\end{array}$ & $\begin{array}{l}\text { - Sodium phosphate dibasic } \\
\text { - Ethanol } \\
\text { - Sorbitan monolaurate } \\
\text { - Sodium saccharin } \\
\text { - Cl } 19.140 \text { and } 15.985 \text { color } \\
\text { - Pomegranate flavor } \\
\text { - Demineralized water }\end{array}$ \\
\hline
\end{tabular}


TABLE 2- Percentage of $S$. aureus strains inhibited (from a total of 28 strains) by each dilution of the tested mouthwashes

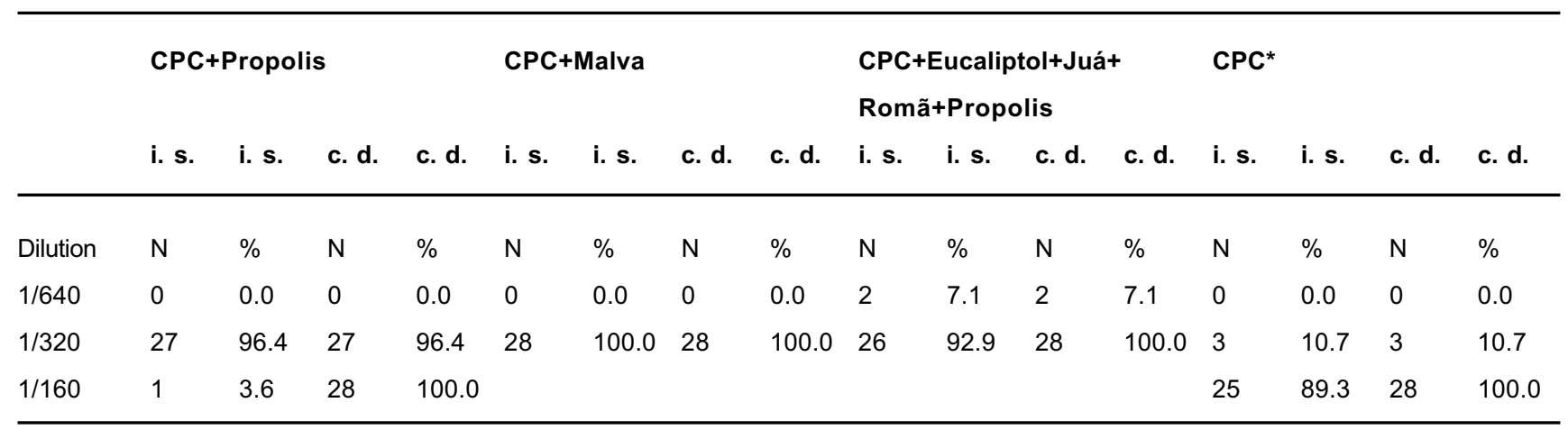

* $(p<0.05)$

i.s. Inhibited strains

c.d. Cumulative data

\section{MID - Mouthwashes with CPC}

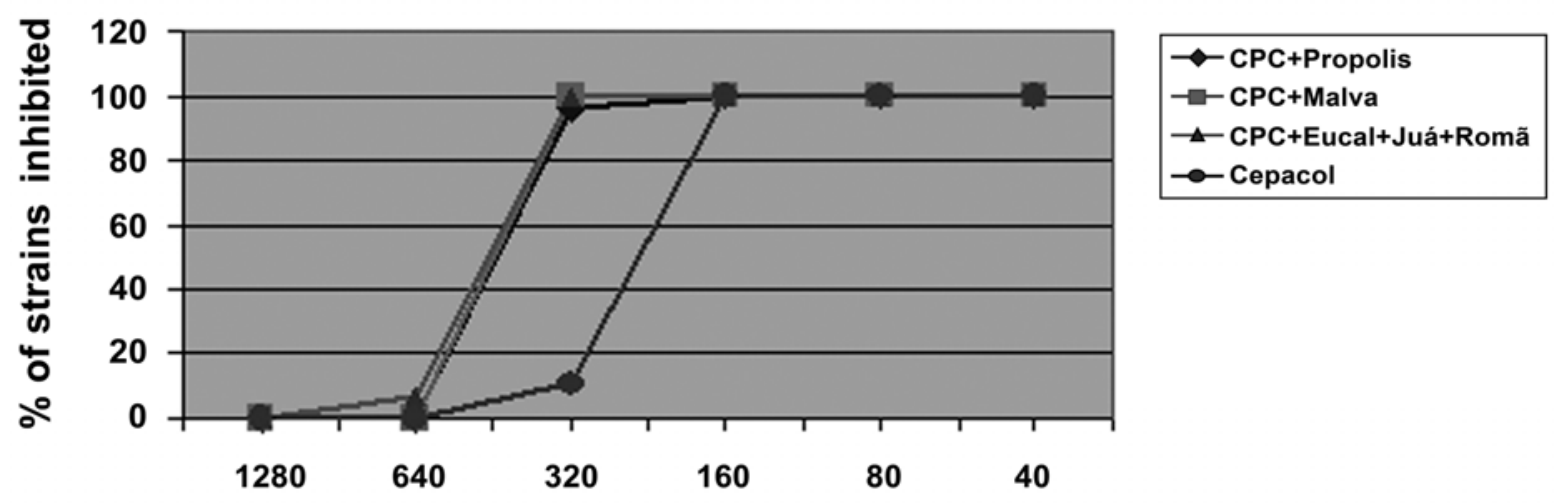

\section{Dilutions}

FIGURE 1- Graph depicting the MID values obtained for each mouthwash

plate has 25 metallic needles that fit into the wells. Using these needles, the inocula were seeded onto the surface of the culture medium in Petri dishes containing different dilutions of the mouthwashes. Since the Steers inoculator has 25 wells and 28 strains were evaluated, three inocula (5 $\mu \mathrm{L}$ ) were seeded equidistantly from each other, approximately $1 \mathrm{~cm}$ from dish periphery, using an automatic pipette.

The dishes were then incubated overnight at $37^{\circ} \mathrm{C}$ and readings were performed considering the MID as the greatest dilution of mouthwash capable of inhibiting the growth of all test strains, following the methodology proposed by Roberts and Addy ${ }^{21}$.

\section{Statistical Analysis}

Results were expressed as scores determined from minimum to maximum dilution. Comparisons among the groups were performed by Friedman's nonparametric test. When this test indicated significant difference between the groups, Dunn's multiple-comparison test, which allows twoby-two comparison between groups, was applied. Significance level was set at $5 \%$.

\section{RESULTS}

The mouthwashes evaluated in this study presented different MIDs (Table 2 and Figure 2).

Statistical analysis demonstrated no statistically significant differences $(\mathrm{p}>0.05)$ among $\mathrm{CPC}+$ Propolis, $\mathrm{CPC}+$ Malva, and $\mathrm{CPC}+$ Eucaliptol+Juá+Romã+Propolis. However, the MID for $\mathrm{Cepacol}^{\circledR}$ was lower than that determined for all other three products $(\mathrm{p}<0.05)$.

\section{DISCUSSION}

CPC is a cationic compound used in oral antiseptics. It has a broad action against bacteria present in the oral cavity $^{21}$. Over $99 \%$ of the microorganisms associated with biofilm/dental plaque formation and gingivitis are eliminated by solutions containing $0.065 \% \mathrm{CPC}^{30}$. A reduction of $39 \%$ in biofilm/dental plaque formation has been observed in brushed surfaces, while this percentage is $25 \%$ in nonbrushed surfaces ${ }^{6,9}$. Roberts and $\operatorname{Addy}^{22}$ (1981) reported a residual effect for 180 to $300 \mathrm{~min}$ following the use of CPC- 
based oral products.

Mouthwashes containing $0.05 \% \mathrm{CPC}$ promote reduction in the amount of salivary microorganisms for $3 \mathrm{~h}$ following $\mathrm{use}^{21}$. One-minute rinsing with $15.0 \mathrm{~mL}$ of CPC-based mouthwash $(0.05 \% \mathrm{CPC})$ for two weeks resulted in an inhibition of biofilm/dental plaque formation when associated with mechanical cleaning ${ }^{24}$. Rawlinson, et al. ${ }^{20}$ (2008) determined the plaque inhibition properties of two formulations of alcohol-free mouthwash with $0.1 \%$ or $0.05 \%$ CPC. They showed that the use of both CPC mouthwashes resulted in less plaque accumulation compared to the control (placebo).

According to the FDA Plaque Subcommittee, CPC is a safe antimicrobial agent for prevention of biofilm formation and gingivitis, when used in concentrations ranging from 0.05 to $0.1 \%{ }^{8}$. In the present study, the products evaluated had a CPC concentration of $0.05 \%$.

According to Albuquerque Jr., et al. ${ }^{1}$ (2004), mouthwashes containing CPC are capable of inhibiting $S$. aureus strains in vitro at a $1 / 20$ dilution. However, in this study, the MID was $1 / 160$ for CPC+Propolis and Cepacol ${ }^{\circledR}$ and $1 / 320$ for $\mathrm{CPC}+$ Malva and CPC+Eucaliptol+Juá+Romã+Propolis.

Several natural extracts have been incorporated to the formulation of oral antiseptics ${ }^{13}$, such as Jupinerus communis, Urtica dioca, Achillaea millefoluim ${ }^{29}$ and Salvadora persica ${ }^{14}$. In the present experiment, three out of the four mouthwashes evaluated contain natural extracts. Based on the obtained results, addition of these extracts to CPC improved its antimicrobial action, as reported elsewhere ${ }^{10}$.

Propolis, a substance present in two of the CPC-based solutions evaluated in the present study, is described as a natural antibiotic produced by bees, and has shown activity against $S$. aureus ${ }^{26}$. However, Silici and Kutluca ${ }^{26}$ (2005) reported only one-weak activity of propolis against the Gram-negative microorganisms Escherichia coli and Pseudomonas aeruginosa.

Malva sylvestris, found in one of the products evaluated in the present study, has been shown to have antiinflammatory action ${ }^{11}$, as well as antimicrobial activity against E. coli and P. aeruginosa ${ }^{2}$. However, according to Coelho de Souza, et al. ${ }^{7}$ (2004), extracts from aerial portions of $M$. sylvestris do not demonstrate activity against $S$. aureus, S. epidermidis, E. coli, Micrococcus luteus, and $C$. albicans. Still according to the same study, only a slight activity was observed against Saccharomyces cerevisiae. Extract from the seed of Malva moschata, a plant found in Scotland, is active against $S$. aureus, $S$. epidermidis, Proteus mirabilis, and E. coli. Nevertheless, extracts obtained from leaves, roots, and seeds may present different effects due to the different concentrations of the active principle in the solutions produced from each of these parts of the plant ${ }^{16}$.

Another natural ingredient added to one of the CPCbased products evaluated is Zizyphus joazeiro extract, which has shown antimicrobial activity against Gram-positive microorganisms ${ }^{25}$.

Eucalyptus, another source of natural extract present in one of the solutions evaluated in the present study, is a genus comprising approximately 600 species of trees, native from Australia. Eucalyptus globulus is the most commonly cultivated species in subtropical and Mediterranean regions, and its natural extract has shown effectiveness against $S$. aureus, E. coli, P.aeruginosa, and C.albicans ${ }^{19}$. Eucalyptus globulus, Eucalyptus maculata, and Eucalyptus viminalis were able to inhibit the growth of several Gram-positive bacteria (S. aureus, MRSA, Bacillus cereus, E. faecalis, Alicyclobacillus acidoterrestrus and Propionibacterium acnes) and one yeast (Trichophyton mentagrophytes). On the other hand, these extracts showed little effectiveness against Gram-negative bacteria (E. coli and P. putida). Nevertheless, Eucalyptus botryoides and Eucalyptus nitens extracts inhibited the growth of both Gram-positive and Gram-negative microorganisms ${ }^{28}$.

Punica granatum (pomegranate) extract is another compound reported as being active against $S$. aureus, $P$. aeruginosa, C. albicans, C. krusei, C. parapsilosis and $C$. tropicalis ${ }^{4}$.

\section{CONCLUSIONS}

According to the proposed methodology and based on the obtained results, it may be concluded that the addition of natural extracts to CPC enhanced its antimicrobial effect.

\section{REFERENCES}

1- Albuquerque RF Jr, Head TW, Mian H, Rodrigo A, Muller K, Sanches $\mathrm{K}$, et al. Reduction of salivary $\mathrm{S}$. aureus and mutans group streptococci by a preprocedural chlorhexidine rinse and maximal inhibitory dilutions of chlorhexidine and cetylpyridinium. Quintessence Int. 2004;35:63540 .

2- Alkofahi A, Batshoun R, Owais W, Najib N. Biological activity of some Jordanian medicinal plant extracts. Fitoterapia. 1996;67:465642 .

3- Block SS. Quaternary ammonium antimicrobial compounds. In: Block SS. Disinfection, sterilization, and preservation. 4th ed. Philadelphia: Lea \& Febiger; 1991. p.225-55.

4- Caceres A, Giron LM, Alvarado SR, Torres MF. Screening of antimicrobial activity of plants popularly used in Guatemala for the treatment of dermatomucosal diseases. J Ethnopharmacol. 1987;20:223-37

5- Centers for Disease Control and Prevention. Staphylococcus aureus with reduced susceptibility to vancomycin-United States. MMWR Morb Mortal Wkly Rep. 1997;46:851.

6- Charles CH, Sharma NC, Galustiam HJ, Qaqish J, Mcguire JA, Vincent JW. Comparative efficacy of an antiseptic mouthrinse and an antiplaque antigingivitis dentifrice: a six-month clinical trial. J Am Dent Assoc. 2001;132:670-5.

7- Coelho de Souza G, Haas APS, von Poser GL, Schapoval EES, Elisabetsky E. Ethnopharmacological studies of antimicrobial remedies in the south of Brazil. J Ethnopharmacol. 2004;90:135-43.

8- Food and Drug Administration. Oral health care drug products for over-the-counter human use. Fed Regist. 2003;68(103). 
9- Gordon JM, Lamster IB, Seiger MC. Efficacy of Listerine antiseptic in inhibiting the development of plaque and gingivitis. J Clin Periodontol. 1985;12:697-704.

10- Gunsolley JC. A meta-analysis of six-month studies of antiplaque and antigingivitis agents. J Am Dent Assoc. 2006;137:1649-57.

11-Han BH, Chi HJ, Han YM, Ryu KS. Screening on the antiinflammatory activity of crude drugs. Korean J Pharmacognosy. $1972 ; 4: 205-9$

12 - Jacobsen PL, Epstein JB, Cohan RP. Understanding "alternative" dental products. Gen Dent. 2001;49:616-20.

13 - Kargermier-Callaway AS, Bredick J, Willershausen B. Effect of three mouthrinses, containing amine/stannous fluoride, herbal extracts or Emser salt on the growth of oral bacteria: an in vitro study. Eur $\mathrm{J}$ Med Res. 2000;29:523-9.

14- Khalessi AM, Pack AR, Thomson WM, Tompkins GR. An in vitro study of the plaque control efficacy of Persica: a commercially available herbal mouthwash containing extracts of Salvadora persica. Int Dent J. 2004;54:279-83.

15- Knighton HT. Study of bacteriophage types and antibiotic resistance of Staphylococci isolated from dental students and faculty members. J Dent Res. 1960;39:906-11.

16- Kumarasamy Y, Cox PJ, Jaspars M, Nahar L, Sarker SD. Screening seeds of Scottish plants for antibacterial activity. J Ethnopharmacol. $2002 ; 83: 73-7$

17- Lowy FD. Staphylococcus aureus infections. N Engl J Med. 1998;339:520-32.

18 - Mandel ID. Chemotherapeutic agents for controlling plaque and gingivitis. J Clin Periodontol. 1988;15:488-98.

19- Panizzi L, Flamini G, Cironi PL, Morelli I. Composition and antimicrobial properties of essential oils of for Mediterranean Laminaceae. J Ethnopharmacol. 1993;39:167-70.

20-Rawlinson A, Pollington S, Walsh TF, Lamb DJ, Marlow I, Haywood J, et al. Efficacy of two alcohol-free cetylpyridinium chloride mouthwashes: a randomized double-blind crossover study. J Clin Periodontol. 2008;35:230-5.

21 - Roberts WR, Addy M. Comparison of the bisbiguanide antiseptic alexidine and chlorhexidine. I. Effect an plaque accumulation and salivary bacteria. J Clin Periodontol. 1981;8:213-9.

22 - Roberts WR, Addy M. Comparison of the in vivo and in vitro antibacterial properties of antiseptic mouthrinses containing chlorhexidine, alexidine, cetylpyridinium chloride and hexetidine. Relevance to mode of action. J Clin Periodontol. 1981;8:295-310.

23 - Salvador MJ, Ferreira EO, Pral EM, Alfieri SC, Albuquerque S, Ito IY, et al. Bioactivity of crude extracts and some constituents of Blutaparon portulacoides (Amaranthaceae). Phytomedicine. 2002;9:566-71.

24- Santos S, Herrera D, López E, O’Connor A, González I, Sanz M A randomized clinical trial on the short-term clinical and microbiological effects of the adjunctive use of a $0.005 \%$ chlorhexidine mouthrinse for patients in supportive periodontal care. J Clin Periodontol. 2004;31:45-51.

25- Schuhly W, Heilmann J, Calis I, Sticher O. New triterpenoids with antibacterial activity from Zizyphus joazeiro. Planta Med. $1999 ; 65: 740-3$
26- Silici S, Kutluca S. Chemical composition and antibacterial activity of propolis collected by three different races of honeybees in the same region. J Ethnopharmacol. 2005;99:69-73.

27- Steers E, Foltz EL, Graves VS. An inocula replicating apparatus for continued testing of bacterial susceptibility to antibiotics. Antibiot Chemother. 1959;9:307-11.

28- Takahashi T, Kokubo R, Sakaino M. Antimicrobial activities of eucalyptus leaf extracts and flavonoids from Eucalyptus maculata. Lett Appl Microbiol. 2004;39:60-4.

29- Van der Weijden GA, Timmerman MF, Reijerse E, Mantel MS, van der Velden $U$. The effect of herbal extracts in an experimental mouthrinse on established plaque and gingivitis. J Clin Periodontol. 1998;25:399-403.

30- Wilt J, Ramji N, Gibb R, Dunavent J, Flood J, Barnes J Antibacterial and antiplaque effects of a novel, alcohol-free oral rinse with cetylpyridinium chloride. J Contemp Dent Pract. 2005;6:15. 